\title{
The Gene Encoding $\gamma$-Glutamyl Transpeptidase II in the Fission Yeast Is Regulated by Oxidative and Metabolic Stress
}

\author{
Hyun-Jung Kang ${ }^{\dagger}$, Byung-Chul Kim ${ }^{\dagger}$, Eun-Hee Park ${ }^{\star}$, Kisup Ahn ${ }^{\S}$ and Chang-Jin Lim ${ }^{\dagger, *}$ \\ 'Division of Life Sciences, College of Natural Sciences, Kangwon National University, Chuncheon 200-701, Korea \\ "College of Pharmacy, Sookmyung Women's University, Seoul 140-742, Korea \\ ${ }^{\S}$ Department of Health and Environment, Baekseok College, Cheonan 330-705, Korea \\ Received 4 July 2005, Accepted 10 August 2005
}

\begin{abstract}
$\gamma$-Glutamyl transpeptidase (GGT, EC 2.3.2.2.) catalyzes the transfer of the $\gamma$-glutamyl moiety from $\gamma$-glutamylcontaining compounds, notably glutathione (GSH), to acceptor amino acids and peptides. A second gene (GGTII) encoding GGT was previously isolated and characterized from the fission yeast Schizosaccharomyces pombe. In the present work, the GGTII-lac $Z$ fusion gene was constructed and used to study the transcriptional regulation of the $S$. pombe GGTII gene. The synthesis of $\beta$-galactosidase from the GGTII-lac $Z$ fusion gene was significantly enhanced by NO-generating SNP and hydrogen peroxide in the wildtype yeast cells. The GGTII mRNA level was increased in the wild-type $S$. pombe cells treated with SNP. However, the induction by SNP was abolished in the Pap1-negative $S$. pombe cells, implying that the induction by SNP of GGTII is mediated by Pap1. Fermentable carbon sources, such as glucose (at low concentrations), lactose and sucrose, as a sole carbon source, enhanced the synthesis of $\beta$ galactosidase from the GGTII-lacZ fusion gene in wildtype KP1 cells but not in Pap1-negative cells. Glycerol, a non-fermentable carbon source, was also able to induce the synthesis of $\beta$-galactosidase from the fusion gene, but other non-fermentable carbon sources such as acetate and ethanol were not. Transcriptional induction of the GGTII gene by fermentable carbon sources was also confirmed by increased GGTII mRNA levels in the yeast cells grown with them. Nitrogen starvation was also able to induce the synthesis of $\beta$-galactosidase from the GGTII-lac $Z$ fusion
\end{abstract}

Abbreviations: GGT, $\gamma$-glutamyl transpeptidase; GSH, glutathione; ONPG, $o$-nitrophenyl- $\beta$-D-galactoside; PCR, polymerase chain reaction; RT-PCR, reverse transcriptase-polymerase chain reaction; $S$. pombe, Schizosaccharomyces pombe; SNP, sodium nitroprusside.

*To whom correspondence should be addressed.

Tel: 82-33-250-8514; Fax: 82-33-242-0459

E-mail: cjlim@kangwon.ac.kr gene in a Pap1-dependent manner. On the basis of the results, it is concluded that the $S$. pombe GGTII gene is regulated by oxidative and metabolic stress.

Keywords: Fission yeast, Fermentable carbon source, $\gamma$ Glutamyl transpeptidase, LacZ fusion, Pap1, Transcriptional regulation, $S$. pombe

\section{Introduction}

$\gamma$-Glutamyl transpeptidase (GGT; EC 2.3.2.2), a membranebound enzyme ubiquitously distributed in living organisms, catalyzes the degradation of extracellular glutathione (GSH, L- $\gamma$-glutamyl-L-cysteinylglycine) by cleavage of the $\gamma$ glutamyl bond, allowing the supply of extracellular cysteine for intracellular synthesis of GSH. GGT is a key enzyme implicated in the homeostasis of intracellular reduced GSH and hence in the regulation of the cellular redox state. GGT cleavage of GSH and the subsequent recapture of cysteine allow living cells to maintain low levels of cellular reactive oxygen species (ROS) and thereby avoid apoptosis induced by oxidative stress (Karp et al., 2001).

There have been known other diverse cellular functions of GGTs. In the budding yeast Saccharomyces cerevisiae, GGT on the vacuolar membrane plays a role in the vacuolar transport and metabolism of the GSH stored in the vacuole serving as an alternative nitrogen source during nitrogen starvation (Mehdi and Penninckx, 1997; Mehdi et al., 2001). In Bacillus subtilis, GGT acts as a powerful exo- $\gamma$-glutamyl hydrolase participating in capsular poly ( $\gamma$-glutamic acid) degradation to supply stationary-phase cells with constituent glutamate (Kimura et al., 2004), and is also important in utilizing GSH as the sole sulfur source (Minami et al., 2004). GGT, reported as a virulence and colonizing factor of Helicobacter pylori, plays an important role on its in vitro 
growth (Gong and Ho, 2004). H. pylori GGT upregulates the expression of COX-2 and EGF-related peptides in human gastric cells through phosphatidylinositol-3 kinase and p38 kinase (Busiello et al., 2004). Meningococcal GGT is processed into two subunits in Neisseria meningitidis, at the conserved amino acid, threonine 427, and the majority of meningococcal GGT is associated with inner membrane facing to the cytoplasmic side (Takahashi and Watanabe, 2004). In the environment of cysteine shortage, like in rat cerebrospinal fluid, meningococcal GGT provides an advantage for meningococcal multiplication by supplying cysteine from environmental $\gamma$-glutamyl-cysteinyl peptides (Takahashi et al., 2004a). Then, detection of GGT activity is used as an identification marker for $N$. meningitidis (Takahashi et al., 2004b). Besides, it has been reported that GGT stimulates the expression of the receptor activator of NF- $\mathrm{B}$ ligand mRNA and protein from bone marrow stromal cells independent of its enzymatic activity (Niida et al., 2004).

The expression of the $S$. cerevisiae GGT gene is highly induced in cells growing on a poor nitrogen source, such as urea, through the GATA zinc-finger transcription factors Nill and Gln3, with Gzf3, another GAZA zinc-finger protein, acting as a negative regulator of nitrogen-source control in the expression of GGT (Springael and Penninckx, 2003). The GGT activity in Candida albicans is influenced by the carbon and nitrogen sources, and its increased GGT activity is responsible for the rapid decrease of the intracellular GSH in C. albicans during the yeast-to-mycelium conversion (Gunasekaran et al. 1995; Manavathu et al. 1996). 4Hydroxynonenal, an electrophilic end product of lipid peroxidation, increases the expression of GGT in rat alveolar type II cells through activation of the ERK and p38 MAPK pathways (Zhang et al., 2005).

A structural gene for $\gamma$-glutamyl transpeptidase, later named GGTI, was previously cloned from the fission yeast Schizosaccharomyces pombe, and its transcription was induced by NO-generating SNP and GSH-depleting L-buthionine(S,R)-sulfoximine (BSO) in a Pap1-dependent way (Park et al., 2004). It was also induced by non-fermentable carbon sources and nitrogen starvation in a Pap1-independent way but not by fermentable carbon sources (Kim et al., 2005). The gene encoding a second $\gamma$-glutamyl transpeptidase, GGTII, was also characterized from $S$. pombe, and its mRNA level was elevated by the treatment with GSH-depleting diethylmaleate (Park et al., 2005). In this continuing work, we demonstrate that the GGTII gene is regulated by oxidative and metabolic stress on a transcriptional level.

\section{Methods and Materials}

Chemicals Ampicillin, bovine serum albumin (BSA), $o$-nitrophenyl$\beta$-D-galactopyranoside (ONPG), L-leucine, uracil, adenine, Dglucose, sucrose, lactose, glycerol, and Bradford reagent were purchased from Sigma Chemical Co. (St. Louis, USA). Restriction enzymes (HindIII and BamHI), T4 DNA ligase, RNaseA, and Ex Taq polymerase were obtained from TaKaRa Shuzo Co. (Shiga, Japan). Yeast extract and agar were obtained from Amersham Life Science (Cleveland, USA). TRIZOL ${ }^{\circledR}$ Reagent and M-MuLV reverse transcriptase were from Invitrogen (Groningen, Netherlands) and Q-BIOgene (Montreal, Canada), respectively. PCR primers were from TaKaRa Shuzo Co. (Shiga, Japan). All other chemicals used were of highest grade commercially available.

Strains and growth conditions E. coli strain MV1184 was used for subcloning, and $S$. pombe $\mathrm{KP} 1\left(h^{+}\right.$leul-32 ura4-294) and TP108-3C ( $h^{-}$leul-32 ura4D18 pap $1::$ ura $\left.^{+}\right)$were used for regulation study. The yeast cells were grown in minimal medium (Kim et al., 2002), which contains $\mathrm{KH}$ phthalate (3 g), $\mathrm{Na}_{2} \mathrm{HPO}_{4}$. $2 \mathrm{H}_{2} \mathrm{O}(2.76 \mathrm{~g}), \mathrm{NH}_{4} \mathrm{Cl}(5 \mathrm{~g})$, D-glucose $(20 \mathrm{~g}), 1,000 \mathrm{X}$ vitamins stock $(1 \mathrm{ml}), 10,000 \mathrm{X}$ minerals stock $(0.1 \mathrm{ml}), 50 \mathrm{X}$ salts stock $(20$ $\mathrm{ml})$, and L-leucine $(250 \mathrm{mg})$ per $1 \mathrm{~L}$. Vitamins stock $(1,000 \mathrm{X})$ contains $81.2 \mathrm{mM}$ nicotinic acid, $55.5 \mathrm{mM}$ inositol, $40.8 \mathrm{mM}$ biotin, and $4.2 \mathrm{mM}$ pantothenic acid. Minerals stock $(10,000 \mathrm{X})$ contains $8.1 \mathrm{mM} \mathrm{H}_{3} \mathrm{BO}_{3}, 2.37 \mathrm{mM} \mathrm{MnSO}_{4}, 1.39 \mathrm{mM} \mathrm{ZnSO}_{4} \cdot 7 \mathrm{H}_{2} \mathrm{O}$, $0.74 \mathrm{mM} \mathrm{FeCl}_{3} \cdot 6 \mathrm{H}_{2} \mathrm{O}, 0.25 \mathrm{mM} \mathrm{MoO} \cdot 2 \mathrm{H}_{2} \mathrm{O}, 0.6 \mathrm{mM} \mathrm{KI}, 0.16$ $\mathrm{mM} \mathrm{CuSO} \cdot 5 \mathrm{H}_{2} \mathrm{O}$, and $4.76 \mathrm{mM}$ citric acid. Salts stock (50X) contains $5.2 \mathrm{mM} \mathrm{MgCl}_{2} \cdot 6 \mathrm{H}_{2} \mathrm{O}, 0.1 \mathrm{mM} \mathrm{CaCl} \cdot 2 \mathrm{H}_{2} \mathrm{O}, 13.4 \mathrm{mM}$ $\mathrm{KCl}$, and $0.28 \mathrm{mM} \mathrm{Na}_{2} \mathrm{SO}_{4}$. The 2-day-grown culture was diluted 50 -fold for inoculation. The yeast cells were shaken at $30^{\circ} \mathrm{C}$, and the yeast growth was monitored by the absorbance at the wavelength of $600 \mathrm{~nm}$.

Cell harvest and disruption The appropriate number of the yeast cells was harvested by centrifugation. The cellular pellets were resuspended in $20 \mathrm{mM}$ Tris buffer ( $\mathrm{pH}$ 7.4)-2 mM EDTA (buffer A) and disrupted using a glass bead beater and a sonicator. Supernatant was obtained after centrifugation and used as crude extract for both enzyme assay and protein determination.

Construction of the GGTII-lac $\boldsymbol{Z}$ fusion gene To separately monitor the expression of the $S$. pombe GGTII gene, the GGTII gene was fused into the promoterless $\beta$-galactosidase gene of the shuttle vector YEp367R as follows. The upstream sequence of the $S$. pombe GGTII gene was amplified from the original plasmid pPHJ02 (Park et al., 2005) by PCR using synthetic primer 1 (5'-gct gcaggaattcaagcttagaaaggaatatatt-3') and primer 2 (5'-ggtagtgtctgta ggatccattacgaaacca-3') which contained HindIII and BamHI sites, respectively. PCR was performed as described in the user's sheet offered by TaKaRa Shuzo Co. The PCR condition used was $94^{\circ} \mathrm{C}$ (denaturation, $1 \mathrm{~min}$ ), $59^{\circ} \mathrm{C}$ (annealing, $1 \mathrm{~min}$ ), and $72^{\circ} \mathrm{C}$ (extension, $1 \mathrm{~min}$ ) for 30 cycles. The amplified DNA fragment was digested with HindIII and BamHI, and ligated into the vector YEp367R digested with HindIII and BamHI. After the transformation into the E. coli strain MV1184, the desired subclone was confirmed by restriction mapping and nucleotide sequencing, and named pGT04. The fusion plasmid pGT04 contains the $940 \mathrm{bp}$ upstream sequence of the GGTII gene ranging -940 to +1 from the translational initiation site. The fusion plasmid pGT04 was used to monitor the expression of the GGTII gene without the interference of the other GGT genes in $S$. pombe. 
$\beta$-Galactosidase assay $\beta$-Galactosidase activity in extracts was determined at $25^{\circ} \mathrm{C}$ by spectrophotometric method using ONPG as a substrate (Guarente, 1983). Its specific activity was represented in $\Delta \mathrm{A}_{420} / \mathrm{min} / \mathrm{mg}$ protein.

Protein determination Protein content in extracts was determined according to the procedure of Bradford using BSA as a standard (Bradford, 1976).

RT-PCR analysis Total RNA was isolated from appropriate $S$. pombe cells using TRIZOL ${ }^{\circledR}$ reagent according to the manufacturer's protocol. First-strand cDNA was synthesized from $2 \mu \mathrm{g}$ total RNA using M-MuLV reverse transcriptase (Lee et al., 2004). One twentieth of the synthesized first-strand cDNA was used as templates in PCR using primer 3 (5'-aaattgctggaacccaatgttaaac-3') and primer 4 (5'-gtttactaagggagatgttattgcgaatt-3'). PCR was performed using Ex Taq polymerase as follows: denaturation at $94^{\circ} \mathrm{C}$ for $1 \mathrm{~min}$, annealing at $55^{\circ} \mathrm{C}$ for $1 \mathrm{~min}$, and extension at $72^{\circ} \mathrm{C}$ for $1 \mathrm{~min}$. The PCR product was approximately $700 \mathrm{bp}$.
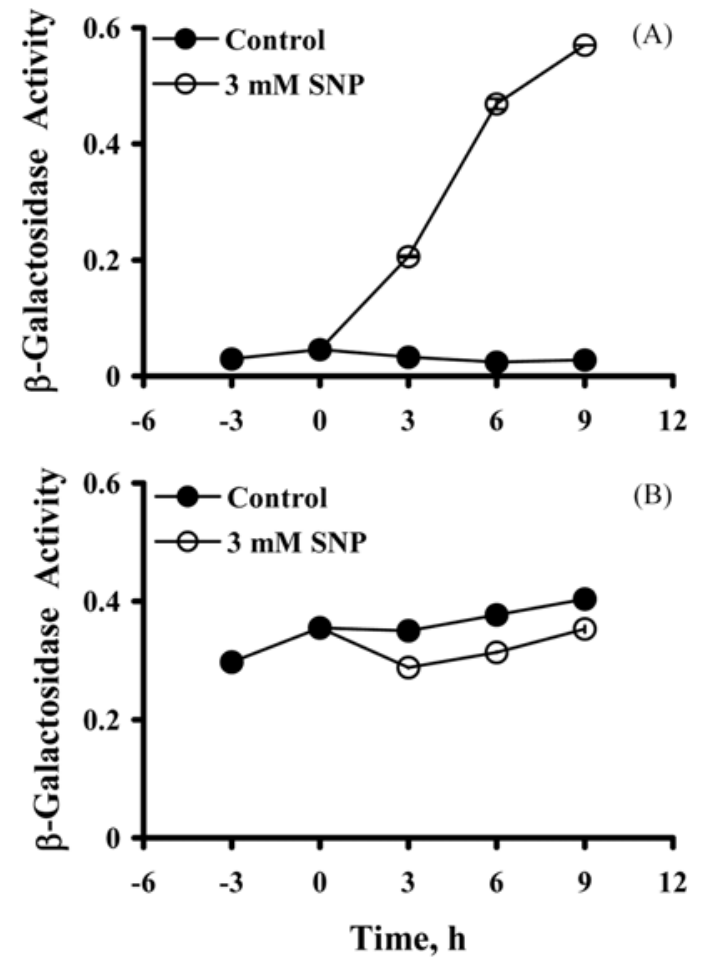

Fig. 1. Effect of sodium nitroprusside (SNP) on the synthesis of $\beta$ galactosidase from the fusion plasmid pGT04 in $S$. pombe wildtype (A) and Pap1-negative TP108-3C (B) cells. The yeast cells harboring plasmid pGT04 were grown in minimal medium, and split at the early exponential phase. Solid circles (- - -) indicate the untreated cells in $\beta$-galactosidase activity. SNP $(-\bigcirc-, 3 \mathrm{mM})$ was added into the appropriate culture flask. The $\beta$-galactosidase activity was determined at $25^{\circ} \mathrm{C}$ by the spectrophotometric assay using ONPG as a substrate, and its specific activity was expressed as $\Delta \mathrm{A}_{420} / \mathrm{min} / \mathrm{mg}$ protein.

\section{Results and Discussion}

In the fission yeast $S$. pombe which resembles higher eukaryotes in aspects of genetics and physiology, there are 3 plausible GGT genes estimated from its nucleotide sequence stored in the GenBank database. To elucidate physiological roles and regulation of GGT in the fission yeast, the first $S$. pombe GGT gene, GGTI, was previously isolated and characterized (Park et al., 2004). It is involved in the response against oxidative stress, and its transcription is enhanced by SNP and GSH depletion in a Pap1-dependent way (Park et al., 2004). It is also induced by non-fermentable carbon sources, such as glycerol, acetate and ethanol, in a Pap1-independent way (Park et al., 2004; Kim et al., 2005). Its response against stress appears to be subject to both Pap1-dependent and Pap1independent modes, which depends on stressful agents. The GGTII gene isolated from the same yeast cells is able to encode a protein of the same amino acid sequence with GGTI, although the nucleotides sequences in both coding regions are

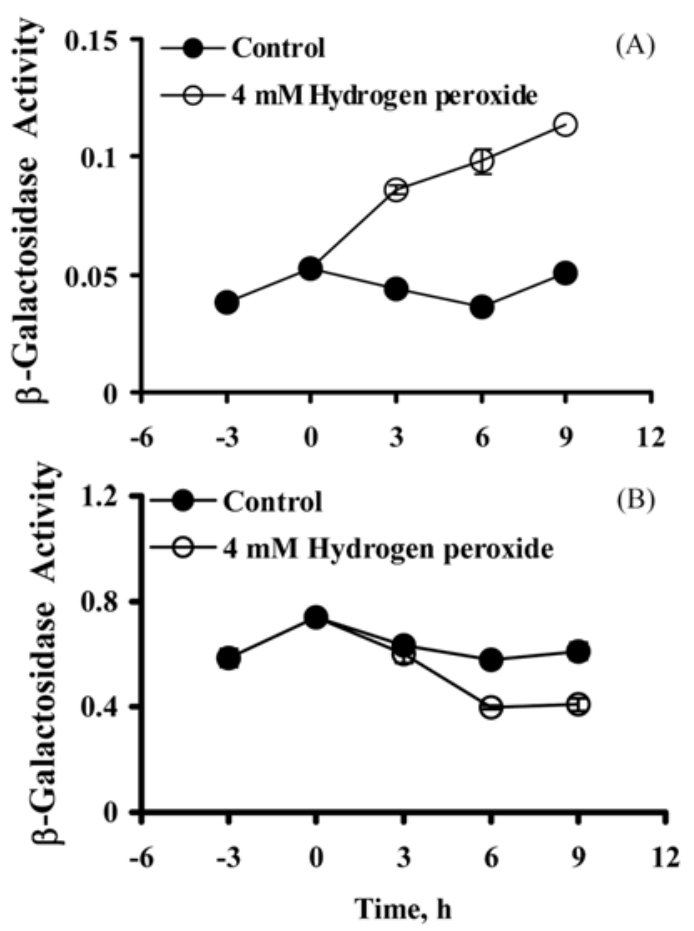

Fig. 2. Effect of hydrogen peroxide on the synthesis of $\beta$ galactosidase from the fusion plasmid pGT04 in $S$. pombe wildtype (A) and Pap1-negative TP108-3C (B) cells. The yeast cells harboring plasmid pGT04 were grown in minimal medium, and split at the early exponential phase. Solid circles (-0-) indicate the untreated cells in $\beta$-galactosidase activity. Hydrogen peroxide (- - -, $4 \mathrm{mM}$ ) was added into the appropriate culture flask. The $\beta$-galactosidase activity was determined at $25^{\circ} \mathrm{C}$ by the spectrophotometric assay using ONPG as a substrate, and its specific activity was expressed as $\Delta \mathrm{A}_{42} \mathrm{~min} / \mathrm{mg}$ protein. 


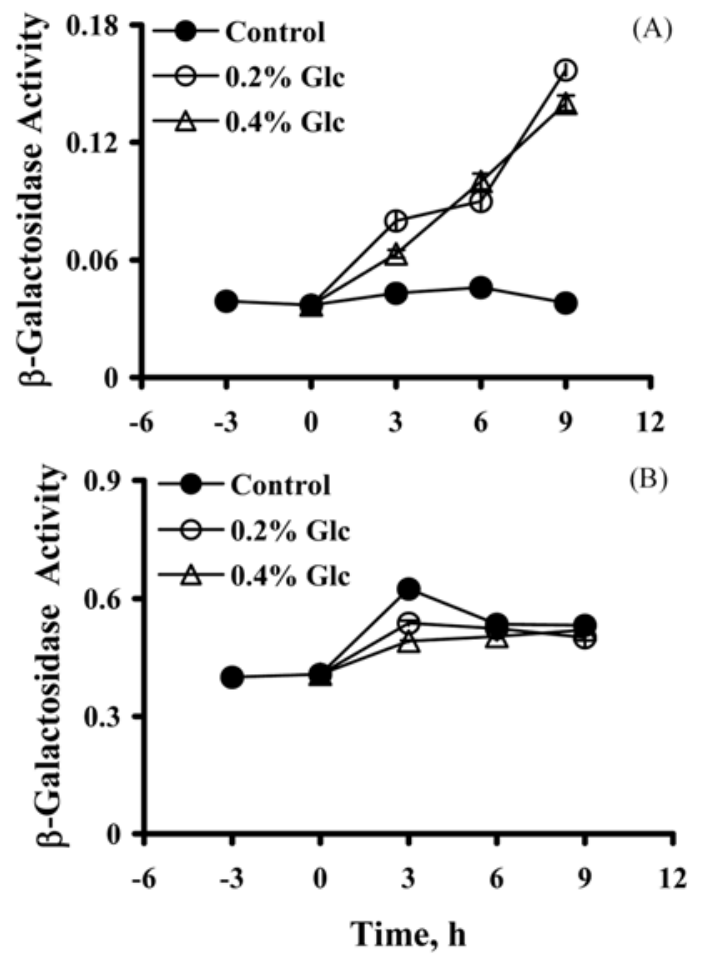

Fig. 3. Effect of glucose at low concentrations on the synthesis of $\beta$-galactosidase from the fusion plasmid pGT04 in $S$. pombe wild-type (A) and Pap1-negative TP108-3C (B) cells. The yeast cells harboring plasmid pGT04 were grown in minimal medium, and split at the early exponential phase. Solid circles (- - -) indicate the untreated cells in $\beta$-galactosidase activity. Glucose ($\bigcirc-, 0.2 \% ;-\triangle-, 0.4 \%$ ), as a sole carbon source instead of $2 \%$ glucose, was added into the appropriate culture flask. The $\beta$ galactosidase activity was determined at $25^{\circ} \mathrm{C}$ by the spectrophotometric assay using ONPG as a substrate, and its specific activity was expressed as $\Delta \mathrm{A}_{420} / \mathrm{min} / \mathrm{mg}$ protein.

different (Park et al., 2005). Accordingly, the two GGT genes have different upstream sequences, which might suggest susceptibility to differential regulation.

Nitrosative and oxidative stress Living cells are equipped with various kinds of defense systems due to their ability to generate highly toxic oxygen-derived free radical species. Simultaneously, metals and oxygen play beneficial roles in enzymatic reaction, metabolism, and signal transduction (Liu and Thiele, 1997). Reactive nitrogen species (RNS) play several roles in physiological and pathological processes, such as metabolism, immunity, inflammation, signal transduction, transcriptional regulation and apoptosis (Marshall et al., 2000; Nathan and Shiloh, 2000). To understand regulation of the GGTII gene against nitrosative and oxidative stress, we measured the synthesis of $\beta$-galactosidase from the GGTIIlacZ fusion plasmid pGT04 in the $S$. pombe cells. The GGTIIlacZ fusion plasmid pGT04 was introduced into $S$. pombe cells. The $S$. pombe culture harboring the fusion plasmid pGT04 was split at the early exponential phase, and treated
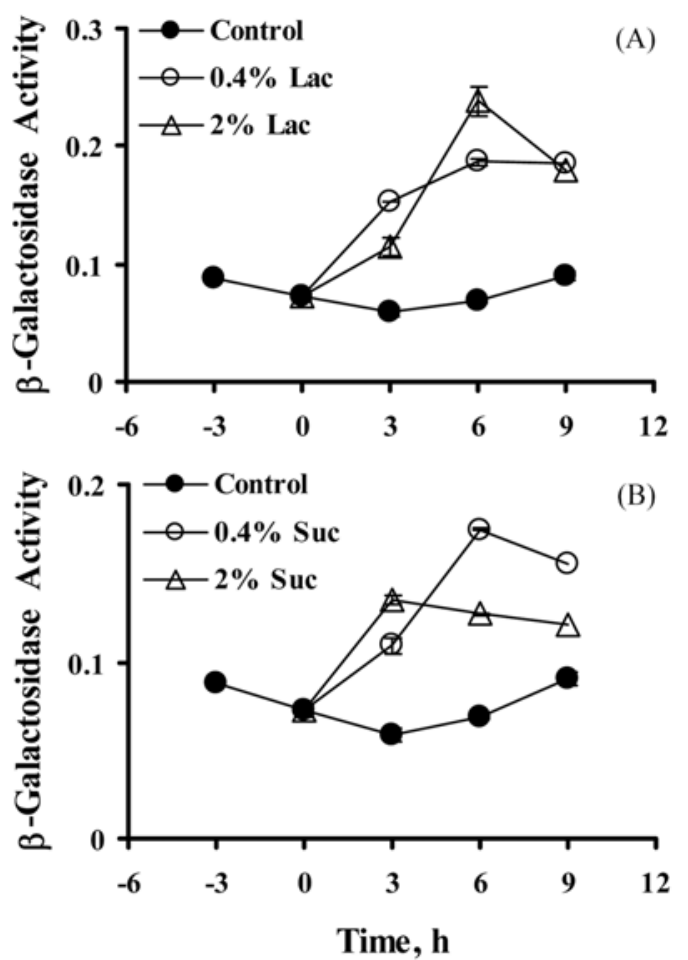

Fig. 4. Effects of fermentable carbon sources, such as lactose and sucrose, on the synthesis of $\beta$-galactosidase from the fusion plasmid pGT04 in wild-type $S$. pombe cells. The yeast cells harboring plasmid pGT04 were grown in minimal medium, and split at the early exponential phase. Solid circles (- - -) indicate the untreated cells in $\beta$-galactosidase activity. Lactose (Lac, A) or sucrose (Suc, B), as a sole carbon source instead of $2 \%$ glucose, was added into the appropriate culture flask (- $\bigcirc-, 0.4 \%$; $-\triangle$-, $2 \%$ ). The $\beta$-galactosidase activity was determined at $25^{\circ} \mathrm{C}$ by the spectrophotometric assay using ONPG as a substrate, and its specific activity was expressed as $\Delta \mathrm{A}_{420} / \mathrm{min} / \mathrm{mg}$ protein.

with $3 \mathrm{mM}$ SNP or $4 \mathrm{mM}$ hydrogen peroxide (Fig. 1, Fig. 2). Though the growth of the yeast cells was slightly delayed by the treatments, it was not arrested (data not shown). As shown in Fig. 1A, SNP markedly enhanced the synthesis of $\beta$ galactosidase from the GGTII-lacZ fusion gene. The yeast cells grown in the presence of $3 \mathrm{mM}$ SNP contained 6.2-, 19.5- and 20.4-fold higher $\beta$-galactosidase activity at 3, 6 and $9 \mathrm{~h}$ after the treatment compared with those in control culture (Fig. 1A). The treatment with $4 \mathrm{mM}$ hydrogen peroxide also gave rise to an enhancement in the synthesis of $\beta$ galactosidase from the GGTII-lacZ fusion gene (Fig. 2A). However, the induction by $3 \mathrm{mM}$ SNP and $4 \mathrm{mM}$ hydrogen peroxide was not observed in the Pap1-negative TP108-3C cells (Fig. 1B, Fig. 2B). The GGTI gene is also induced by SNP but not by hydrogen peroxide (Park et al., 2004). Collectively, the $S$. pombe GGTII gene is induced by nitrosative and oxidative stress.

Regulation by carbon sources Glucose is a powerful signaling molecule which promotes major metabolic changes 

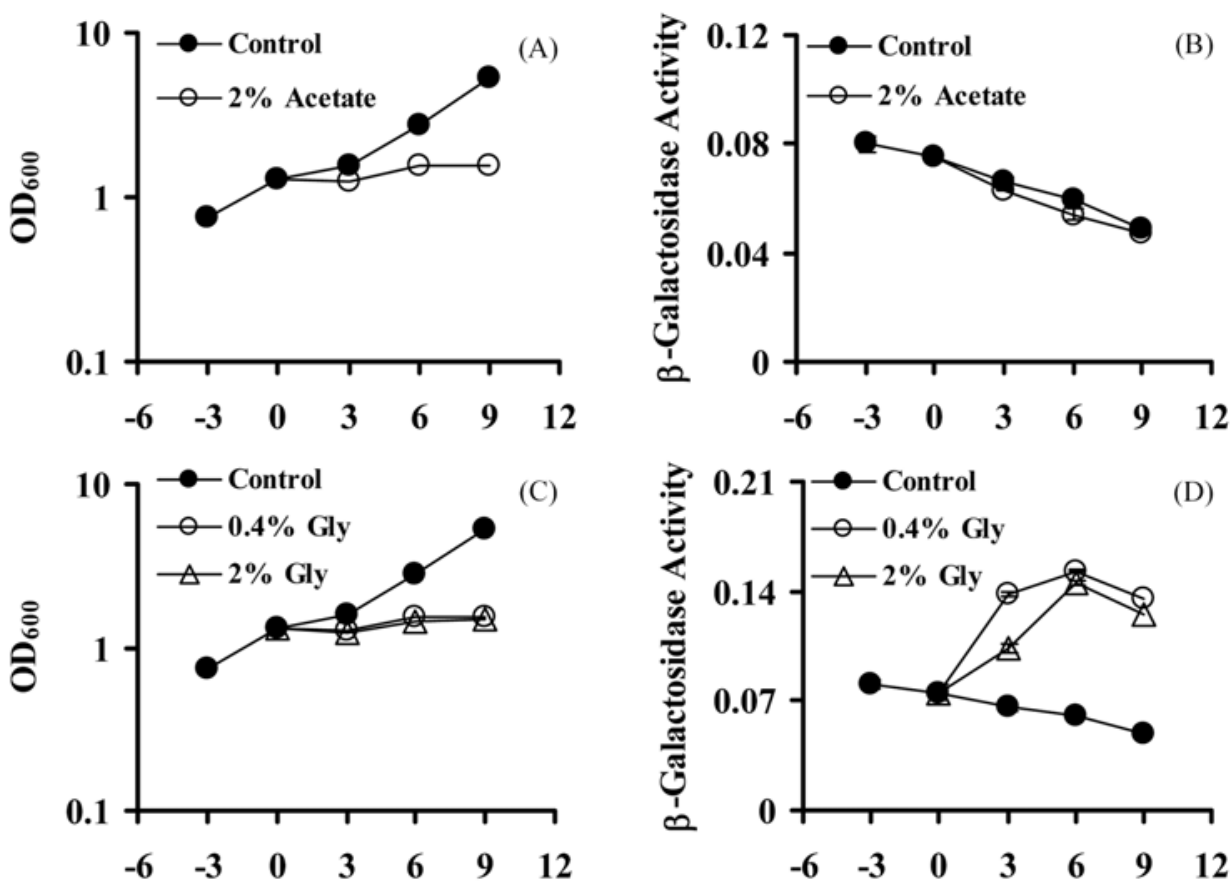

Time, h

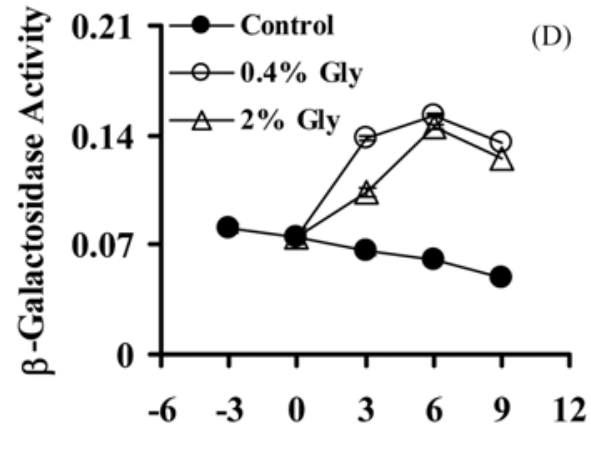

Time, $\mathbf{h}$

Fig. 5. Effects of non-fermentable carbon sources, such as potassium acetate and glycerol, on the synthesis of $\beta$-galactosidase from the fusion plasmid pGT04 in wild-type $S$. pombe cells. The yeast cells harboring plasmid pGT04 were grown in minimal medium, and split at the early exponential phase. Solid circles (-O-) indicate the untreated cells in growth curves (A, C) and $\beta$-galactosidase activity (B, D). Potassium acetate $\left(-\bigcirc_{-}, 2 \%\right)$ or glycerol $\left(-\bigcirc_{-}, 0.4 \% ;-\triangle-, 2 \%\right)$, as a sole carbon source instead of $2 \%$ glucose, was added into the appropriate culture flask. The $\beta$-galactosidase activity was determined at $25^{\circ} \mathrm{C}$ by the spectrophotometric assay using ONPG as a substrate, and its specific activity was expressed as $\Delta \mathrm{A}_{420} / \mathrm{min} / \mathrm{mg}$ protein.

in living cells (Rolland et al., 2001). Metabolism of glucose produces compounds directly linked to the detoxification of intracellular hydroperoxides formed as byproducts by ongoing metabolic processes (Spitz et al., 2000). Therefore, deprivation of glucose causes a strong metabolic oxidative stress which is characterized by increased steady-state levels of intracellular hydroperoxides and glutathione disulfide (Lee et al., 1998; Song et al., 2002). Since the S. pombe GGTI gene is induced by non-fermentable carbon sources, effects of various carbon sources were examined on the synthesis of $\beta$-galactosidase from the GGTII-lacZ fusion gene. As a sole carbon source, glucose (low concentrations, $0.2 \%, 0.4 \%)$, lactose $(0.4 \%$, $2.0 \%)$, sucrose $(0.4 \%, 2.0 \%)$, glycerol $(0.4 \%, 2.0 \%)$ and acetate $(2.0 \%)$ were substituted for $2 \%$ glucose in minimal medium (Fig. 3, Fig. 4, Fig. 5). As shown in Fig. 3, substitution of glucose at low concentrations markedly increased the synthesis of $\beta$-galactosidase from the GGTIIlac $Z$ fusion gene. Glucose at lower concentration gave higher induction in the synthesis of $\beta$-galactosidase from the GGTIIlac $Z$ fusion gene (Fig. 3). The glucose concentrations used did not change the growth of the yeast cultures largely (data not shown). Other fermentable carbon sources such as lactose and sucrose were also able to enhance the synthesis of $\beta$ galactosidase from the GGTII-lacZ fusion gene in the wildtype yeast cells, but each of them showed slightly different degrees of inductions (Fig. 4A, 4B). However, lactose nearly arrested the growth of the yeast cultures (data not shown). Growth of the budding yeast on non-fermentable carbon sources, such as glycerol, lactate, ethanol or acetate, requires the coordinated expressions of several genes, which are dispensable in the presence of substrates easily utilized by glycolysis (e.g. glucose or fructose) (Hiesinger et al., 2001). In an $S$. pombe culture containing the fusion plasmid pGT04 at the early exponential phase grown in supplemented minimal medium, a switch was made from $2 \%$ glucose to $2 \%$ potassium acetate, $0.4 \%$ and $2.0 \%$ glycerol or $2 \%$ ethanol as a sole carbon source. The $\beta$-galactosidase activity was measured at 3, 6 and $9 \mathrm{~h}$ after the switch. A switch to potassium acetate and glycerol gave rise to an arrest in the growth of the treated culture (Fig. 5A, Fig. 5C). A switch to glycerol could induce the synthesis of $\beta$-galactosidase from the fusion gene in the wild-type $S$. pombe cells (Fig. 5D). However, a switch to $2 \%$ potassium acetate could not affect the synthesis of $\beta$-galactosidase from the GGTII-lac $Z$ fusion gene (Fig. 5B). A switch to $2 \%$ ethanol, the other nonfermentable carbon source used in this study, showed similar patterns in growth and $\beta$-galactosidase of the yeast cultures (data not shown). It was previously shown that the GGTI gene was induced by non-fermentable carbon sources but not by fermentable carbon sources (Kim et al., 2005). From the 


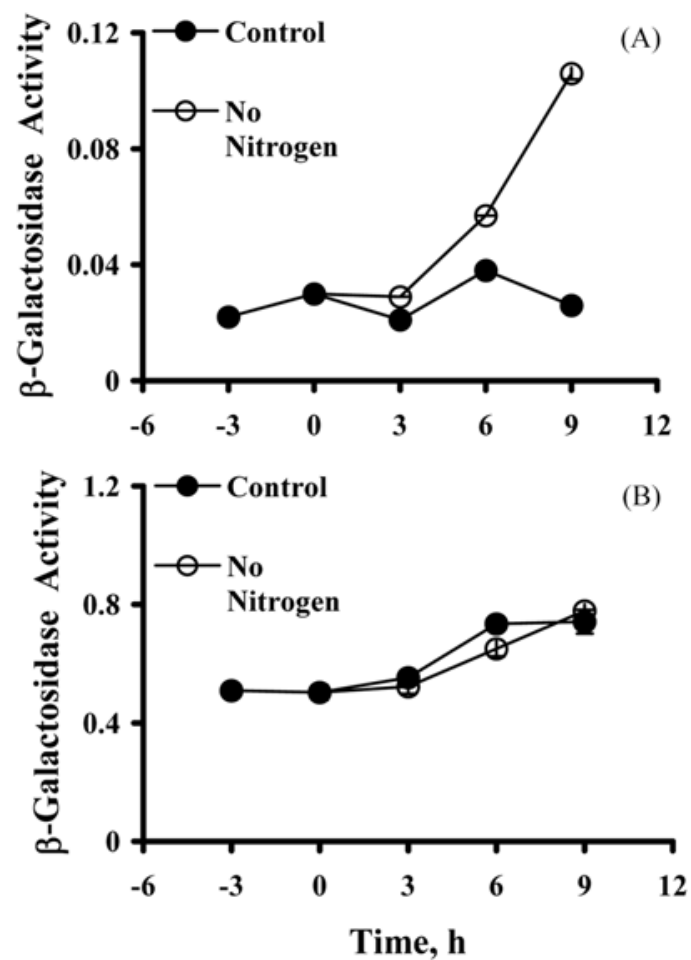

Fig. 6. Effect of nitrogen starvation on the synthesis of $\beta$ galactosidase from the fusion plasmid pGT04 in $S$. pombe wildtype (A) and Pap1-negative TP108-3C (B) cells. The yeast cells harboring plasmid pGT04 were grown in minimal medium, and split at the early exponential phase. Solid circles (-O-) indicate the untreated cells in $\beta$-galactosidase activity. Ammonium chloride, a nitrogen source in the untreated cells, was starved in the appropriate flask (- $\bigcirc-)$. The $\beta$-galactosidase activity was determined at $25^{\circ} \mathrm{C}$ by the spectrophotometric assay using ONPG as a substrate, and its specific activity was expressed as $\Delta \mathrm{A}_{420}$ l $\mathrm{min} / \mathrm{mg}$ protein.

current and previous studies, glycerol was found to induce both GGTI and GGTII genes in $S$. pombe, the physiological meaning of which still remains to be solved. Taken together, the results indicate that the two GGT genes are subject to differential regulation responding carbon sources.

Nitrogen starvation Adaptation of cells to nutritional stress is paralleled by alterations in the expression of the responsible genes, which may be associated with selective degradation of superfluous proteins. In $S$. cerevisiae, expression of the CIS2 gene encoding GGT, the main GSH-degrading enzyme, is highest in cells growing on a poor nitrogen source, such as urea (Springael and Penninckx, 2003). During growth on a preferred nitrogen source, like $\mathrm{NH}_{4}^{+}, C I S 2$ expression is repressed through the mechanism involving the Gln3-binding protein, Ure2/GdhCR (Springael and Penninckx, 2003). When ammonium-grown $S$. pombe KP1 cells harboring the fusion plasmid pGT04 were transferred to a minimal medium lacking a nitrogen source, the synthesis of $\beta$-galactosidase from the GGTII-lacZ fusion gene was significantly enhanced
3 mM SNP

\begin{tabular}{llllll}
0 & 3 & 6 & 9 & hour \\
& & & & & \\
\hline & & & & &
\end{tabular}
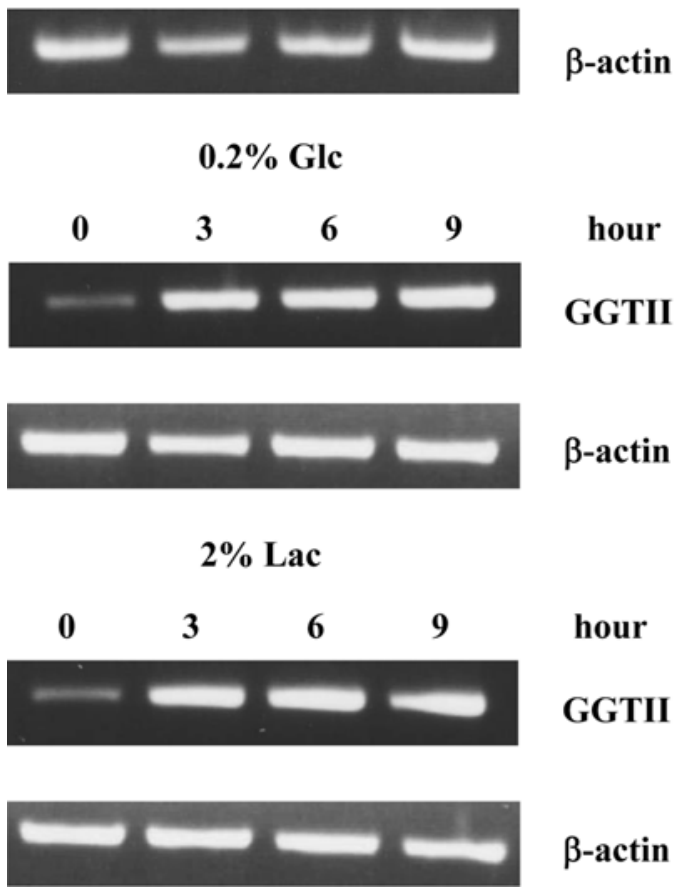

Fig. 7. Variations in the GGTII mRNA level of the wild-type $S$. pombe cells treated with $3 \mathrm{mM}$ sodium nitroprusside (SNP), $0.2 \%$ glucose (Glc) or $2 \%$ lactose (Lac). Total mRNA was isolated at 3, 6 and 9 hours after the treatments. The GGTII mRNA was detected using RT-PCR as described in 'Materials and Methods'. A representative of three separate experiments is shown.

(Fig. 6). Six hours after the exposure to nitrogen-starved conditions, the synthesis of $\beta$-galactosidase in the yeast cells rose 4.1-fold (Fig. 6). In conclusion, the expression of the $S$. pombe GGTII gene, like the GGTI gene (Kim et al., 2005), is induced under nitrogen starvation.

Pap1-dependence The yeast cells are known to induce the transcription of genes required for detoxification of stressful agents (Lee et al., 2003). The two transcription factors, Pap1 and Atf1, are believed to be responsible for the induction of stress-related genes in the fission yeast $S$. pombe (Nguyen et al., 2000). To find whether Pap1 is involved in the induction of the $S$. pombe GGTII gene by SNP, fermentable carbon sources and nitrogen starvation, the Pap1-negative $S$. pombe strain TP108-3C was used. The TP108-3C cells harboring the fusion plasmid pGT04 were exposed to SNP, fermentable carbon sources and nitrogen starvation, and the $\beta$-galactosidase activities in the treated cells were measured. The TP108-3C cells harboring the fusion plasmid could not gave rise to any changes in the synthesis of $\beta$-galactosidase from the GGTII- 


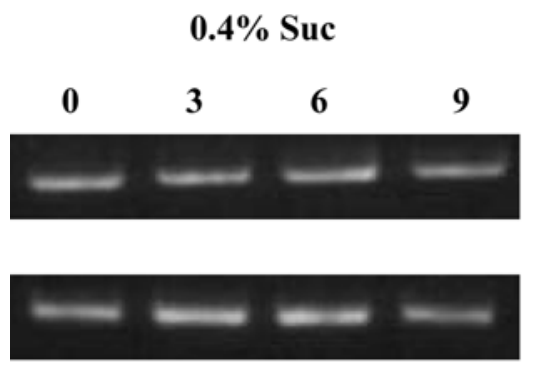

hour

GGTII

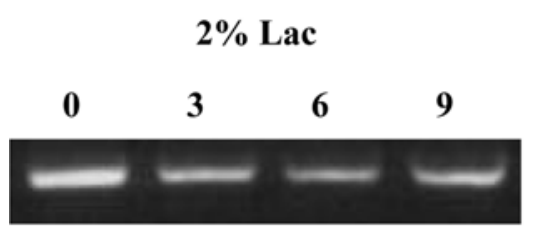

hour

GGTII

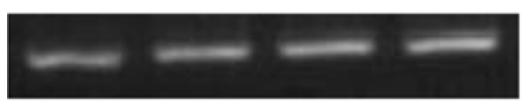

$\beta$-actin

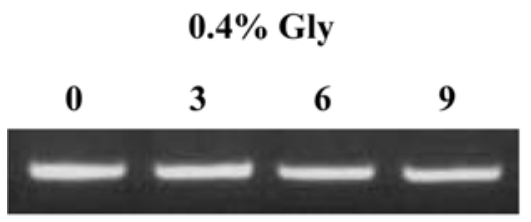

hour

GGTII

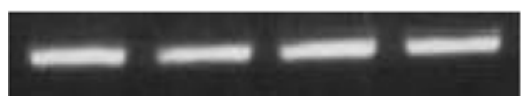

$\beta$-actin

Fig. 8. Variations in the GGTII mRNA level of the Pap1negative mutant TP108-3C cells treated with lactose, sucrose or glycerol as a sole carbon source. Total mRNA was isolated at 3, 6 and 9 hours after the treatments. The GGTII mRNA was detected using RT-PCR as described in 'Materials and Methods'.

lacZ fusion gene when treated with SNP (Fig. 1B), glucose at low concentrations (Fig. 3B) and nitrogen starvation (Fig. $6 \mathrm{~B})$. These results indicate that the GGTII gene is regulated by SNP, carbon sources and nitrogen starvation in a Pap1dependent manner. Though the induction by SNP of the GGTI gene is also mediated by Pap1, its induction by nitrogen starvation does not require the presence of Pap1 (Park et al., 2004; Kim et al., 2005). Therefore, it is assumed that the two GGT genes are subject to differential mechanisms to induce their expressions in response to nitrogen starvation.

mRNA level To confirm the induction of the GGTII gene on the transcriptional level, the GGTII mRNA level was measured using RT-PCR in the wild-type $S$. pombe cells treated with $3 \mathrm{mM} \mathrm{SNP}, 0.2 \%$ glucose, and 2\% lactose (Fig. 7). As shown in Fig. 7, the GGTII mRNA level was significantly increased after all the treatments. However, the GGTII mRNA level in the Pap1-negative TP108-3C cells was not increased by sucrose, lactose and glycerol (Fig. 8). These results confirm that the transcriptional induction of the GGTII gene occurs in a Pap1-dependent manner. In brief, the GGTII
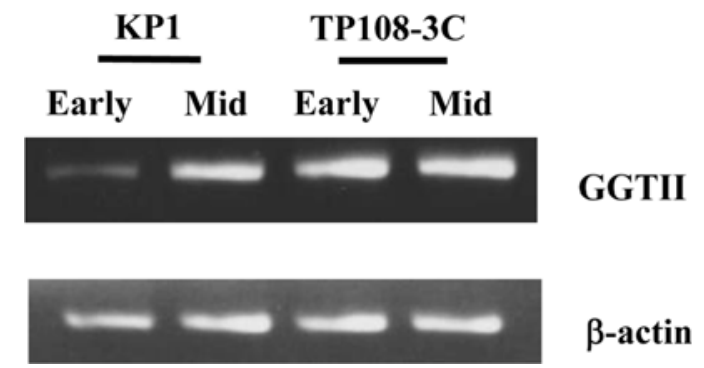

Fig. 9. Expression patterns of the GGTII gene in wild-type KP1 and Pap1-negative TP108-3C S. pombe cells. The cells were harvested at the early and mid- exponential phases, which were denoted as 'Early' and 'Mid', respectively. RT-PCR analysis was preformed to detect gene expression using specific primers for GGTII and $\beta$-actin mRNAs.

gene is transcriptionally regulated by nitrosative stress and fermentable carbon sources. In shift experiments, it was observed that the $\beta$-galactosidase activity in TP108-3C cells was much higher than that in wild-type cells. To explain this fact, the GGTII mRNA level was detected in wild-type and TP108-3C cells at early and mid- exponential phases (Fig. 9). The TP108-3C cells gave rise to much higher GGTII mRNA level at early exponential phase than the wild-type cells, which corresponded with the results obtained with the GGTIIlacZ fusion gene. This suggests that the basal expression of the GGTII gene may be repressed by Pap1, at least in early exponential phase.

The yeast growth in the absence of glucose relies on the breakdown of partially oxidized substrates that are derived from fermentative reactions. The carbon source-responsive element (CSRE) mediates transcriptional activation of the gluconeogenic genes during the growth of the yeast $S$. cerevisiae on non-fermentable carbon sources (Vincent and Carlson, 1998). A few plausible CSRE motifs, which corresponds to the consensus $\mathrm{CCN}_{6} \mathrm{CCG}$ sequence typical of a subfamily among zinc cluster proteins (Walther and Schuller, 2001), are identified in the upstream regions of both GGTI and GGTII genes (Fig. 10). Though their roles remain unknown, one or some CSRE motifs might work for the induction of the GGTI gene by non-fermentable carbon sources.

There are two known stress signal pathways in the fission yeast $S$. pombe. The one is the Spc1-Atf1 pathway in which stress-activated Spc1 induces Atf1, and the other is mediated by Pap1 independently of Spc1 activation (Nguyen et al., 2000). The expression of the $S$. pombe glutathione synthetase gene was reported to be regulated by the Spc1-Atf1 pathway (Kim et al., 2003). A transcription factor Pap1 required for survival to oxidative stress shows high homology to mammalian c-Jun like its $S$. cerevisiae homologue Yap1 (Toda et al., 1991). The $S$. pombe cells deleted in pap $1^{+}$show high sensitivity to oxidative stress but not to osmotic stress or nutrient deprivation (Toone et al., 1998). Spc1 is activated by high osmolarity, oxidative stress, and heat shock (Millar et al., 1995; Shiozaki and Russell, 1995; Kato et al., 1996). Several 


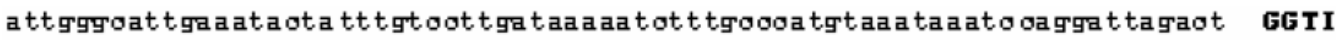
a aagtgagaa agraa tata ttgaagtaagt aoogotaotoaa atgaga tgaatgota aagaa tgogtt GGr I

a aoa oa toa aajttgaat taa togatgagttaaaatgaa togott togaoootatta tattagttttat G6rI a otgogt ot toa o tooaga gaa ta gyototgagtagot a poga totgogttaaaagotgtga otat GGr I

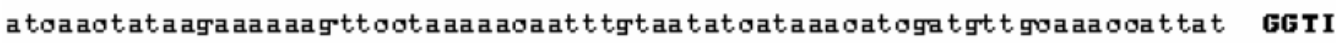

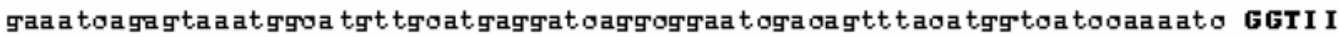

taga oagataga gaaga otaoaaaa toaaataoatttaataoogatttotattatotatotttoatg GGTI

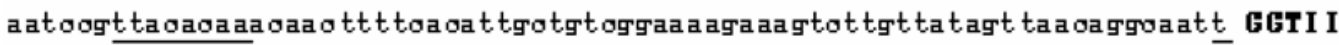

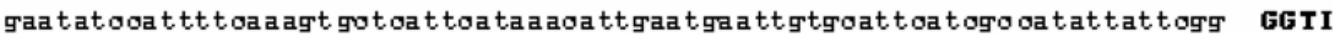

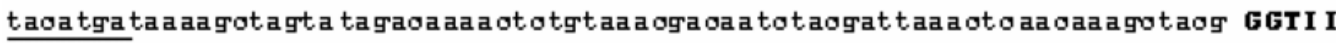

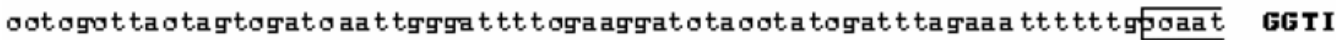

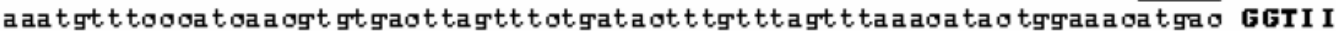

Fig. 10. Comparison in the upstream sequences of the two GGT genes, GGTI and GGTII, in the fission yeast $S$. pombe. Plausible Pap1 binding sites are underlined, whereas plausible CSRE motifs are boxed.

reports have shown that carbon starvation is an environmental stress able to activate the MAPK Sty1 in $S$. pombe (Stelttler et al., 1996; Shiozaki et al., 1997). Recently, glucose limitation in $S$. pombe not only promotes activation of the SAPK signaling pathway resulting in increased expression of Atf1dependent stress-related genes but also induces an oxidative stress that favors the concerted expression of additional genes depending on the transcription factor Pap1 (Madrid et al., 2004). The consensus sequence for the binding site of the Pap1 protein was previously determined to be TTACGTAA (Fujii et al., 2000). The five plausible Pap1 binding sites are found at the upstream region of the $S$. pombe GGTII gene, whereas the only plausible Pap1 site is located at the upstream region of the GGTI gene (Fig. 10). Some of them may be responsible for the regulation by the Pap1 protein in the induction of the $S$. pombe GGTI and GGTII genes. Atf1 is most homologous to ATF-2, a key substrate of the human SAPKs, p38 and c-Jun N-terminal kinases (Gupta et al., 1995; Livingstone et al., 1995; van Dam et al., 1995; Raingeaud et al., 1996), which underscores the high conservation between the $S$. pombe and human SAPK pathways. The consensus sequence for the binding site of the Atf1 protein was previously determined to be TGAGGTCAG (Degols and Russell, 1997). Plausible Atf1 binding sites are not identified at the upstream regions of the $S$. pombe GGT genes (Fig. 10). However, the detailed mechanisms in the regulation of the $S$. pombe GGT genes requires further approaches.

Acknowledgments This work was supported by a Korea Research Foundation grant (KRF-2002-070-C00062). 


\section{References}

Bradford, M. M. (1976) A rapid and sensitive method for the quantitation of microgram quantities of protein utilizing the principle of protein-dye binding. Anal. Biochem. 72, 248-254.

Busiello, I., Acquaviva, R., Di Popolo, A., Blanchard, T. G., Ricci, V., Romano, M. and Zarrilli, R. (2004) Helicobacter pylori $\gamma$ glutamyltranspeptidase upregulates $\mathrm{COX}-2$ and EGF-related peptide expression in human gastric cells. Cell. Microbiol. 6, 255-267.

Degols, G. and Russell, P. (1997) Discrete roles of the Spc1 kinase and the Atfl transcription factor in the UV response of Schizosaccharomyces pombe. Mol. Cell. Biol. 17, 3356-3363.

Fujii, Y., Shimizu, T., Toda, T., Yanagida, M. and Hakoshima, T. (2000) Structural basis for the diversity of DNA recognition by bZIP transcription factors. Nat. Struct. Biol. 7, 889-893.

Gong, M. and Ho, B. (2004) Prominent role of $\gamma$-glutamyl transpeptidase on the growth of Helicobacter pylori. World $J$. Gastroenterol. 10, 2994-2996.

Guarente, L. (1983) Yeast promoters and lacZ fusions designed to study expression of cloned genes in yeast. Methods Enzymol. 101, 181-191.

Gunasekaran, S., Imbayagwo, M., McDonald, L., Gunasekaran, M. and Manavathu, E. (1995) Influence of carbon and nitrogen sources on glutathione catabolic enzymes in Candida albicans during dimorphism. Mycopathol. 131, 92-97.

Gupta, S., Campbell, D., De'rijard, B. and Davis, R. J. (1995) Transcription factor ATF2 regulation by the JNK signal transduction pathway. Science 267, 389-393.

Hiesinger, M., Roth, S., Meissner, E. and Schüller, H.-J. (2001) Contribution of Cat8 and Sip4 to the transcriptional activation of yeast gluconeogenic genes by carbon source-responsive elements. Curr. Genet. 39, 68-76.

Karp, D. R., Shimooku, K. and Lipsky, P. E. (2001) Expression of $\gamma$-glutamyl transpeptidase protects Ramos B cells from oxidation-induced cell death. J. Biol. Chem. 276, 3798-3804.

Kato, T., Okazaki, K., Murakami, H., Stettler, S., Fantes, P. and Okayama, H. (1996) Stress signal, mediated by a Hog1-like MAP kinase, controls sexual development in fission yeast. FEBS Lett. 378, 207-212.

Kim, H. G., Park, H. J., Kang, H. J., Lim, H. W., Kim, K., Park, E. H., Ahn, K. and Lim, C. J. (2005) The Schizosaccharomyces pombe gene encoding $\gamma$-glutamyl transpeptidase I is regulated by non-fermentable carbon sources and nitrogen starvation. $J$. Microbiol. 43, 44-48.

Kim, M., Lim, C. J. and Kim, D. (2002) Transcription of Schizosaccharomyces pombe thioltransferase-1 in response to stress conditions. J. Biochem. Mol. Biol. 35, 409-413.

Kim, S. J., Shin, Y. H., Kim, K., Park, E. H., Sa, J. H. and Lim, C. J. (2003) Regulation of the gene encoding glutathione synthetase from the fission yeast. J. Biochem. Mol. Biol. 36, 326-331.

Kimura, K., Tran, L. S., Uchida, I. and Itoh, Y. (2004) Characterization of Bacillus subtilis $\gamma$-glutamyltranspeptidase and its involvement in the degradation of capsule poly-gammaglutamate. Microbiol. 150, 4115-4123.

Lee, J. E., Park, M. H. and Park, J. H. (2004) The gene expression profile of cyst epithelial cells in autosomal dominant polycystic kidney disease patients. J. Biochem. Mol. Biol. 37, 612-617.
Lee, Y.-Y., Kim, S.-J., Park, E.-H. and Lim, C.-J. (2003) Glutathione content and the activities of glutathione synthesizing enzymes in fission yeast are modulated by oxidative stress. J. Microbiol. 41, 248-251.

Lee, Y. J., Galoforo, S. S., Berns, C. M., Chen, J. C., Davis, B. H., Sim, J. E., Corry, P. M. and Spitz, D. R. (1998) Glucose deprivation-induced cytotoxicity and alterations in mitogenactivated protein kinase activation are mediated by oxidative stress in multidrug-resistant human breast carcinoma cells. $J$. Biol. Chem. 273, 5294-5299.

Liu, X. D. and Thiele, D. J. (1997) Yeast metallothionein gene expression in response to metals and oxidative stress. Methods Enzymol. 11, 289-299.

Livingstone, C., Patel, G. and Jones, N. (1995) ATF-2 contains a phosphorylation-dependent transcriptional activation domain. EMBO J. 14, 1785-1797.

Madrid, M., Soto, T., Franco, A., Paredes, V., Hidalgo, E., Gracto, M. and Cansado, J. (2004) A cooperative role for Atfl and Pap1 in the detoxification of the oxidative stress induced by glucose deprivation in Schizosaccharomyces pombe. J. Biol. Chem. 279, 41594-41602.

Manavathu, M., Gunasekaran, S., Porte, Q., Manavathu, E. and Gunasekaran, M. (1996) Changes in glutathione metabolic enzyme during yeast-to-mycelium conversion of Candida albicans. Can. J. Microbiol. 42, 76-79.

Marshall, H. F., Merchant, K. and Stamler, J. S. (2000) Nitrosation and oxidation in the regulation of gene expression. FASEB $J$. 14, 1889-1900.

Mehdi, K. and Penninckx, M. J. (1997) An important role for glutathione and $\gamma$-glutamyltranspeptidase in the supply of growth requirements during nitrogen starvation of the yeast Saccharomyces cerevisiae. Microbiol. 143, 1885-1889.

Mehdi, K., Thierie, J. and Penninckx, M. J. (2001) $\gamma$-Glutamyl transpeptidase in the yeast Saccharomyces cerevisiae and its role in the vacuola transport and metabolism of glutathione. Biochem. J. 359, 631-637.

Millar, J., Buck, V. and Wilkinson, M. (1995) Pyp1 and Pyp2 PTPases dephosphorylate an osmosensing MAP kinase controlling cell size at division in fission yeast. Genes Dev. 9, 2117-2130.

Minami, H., Suzuki, H. and Kumagai, H. (2004) $\gamma$ Glutamyltranspeptidase, but not $\mathrm{YwrD}$, is important in utilization of extracellular glutathione as a sulfur source in Bacillus subtilis. J. Bacteriol. 186, 1213-1214.

Nathan, C. and Shiloh, M. U. (2000) Reactive oxygen and nitrogen intermediates in the relationship between mammalian hosts and microbial pathogens. Proc. Natl. Acad. Sci. USA 97, 8841-8848.

Nguyen, A. N., Lee, A., Place, W. and Shiozaki, K. (2000) Multistep phosphorelay proteins transmit oxidative stress signals to the fission yeast stress-activated protein kinase. Mol. Biol. Cell 11, 1169-1181.

Niida, S., Kawahara, M., Ishizuka, Y., Ikeda, Y., Kondo, T., Hibi, T., Suzuki, Y., Ikeda, K. and Taniguchi, N. (2004) $\gamma$ Glutamyltranspeptidase stimulates receptor activator of nuclear factor-kappaB ligand expression independent of its enzymatic activity and serves as a pathological bone-resorbing factor. $J$. Biol. Chem. 279, 5752-5756.

Park, H.-J., Moon, J.-S., Kim, H.-G., Kim, I.-H., Kim, K., Park, E.-H. and Lim, C.-J. (2005) Characterization of a second gene 
encoding $\gamma$-glutamyl transpeptidase from Schizosaaccharomyces pombe. Can. J. Microbiol. 51, 269-275.

Park, H. J., Lim, H. W., Kim, K., Kim, I. H., Park, E. H. and Lim, C. J. (2004) Characterization and regulation of the $\gamma$ glutamyl transpeptidase gene from the fission yeast Schizosaccharomyces pombe. Can J. Microbiol. 50, 61-66.

Raingeaud, J., Whitmarsh, A. J., Barrett, T., De'rijard, B. and Davis, R. J. (1996) MKK3- and MKK6-regulated gene expression is mediated by the p38 mitogen- activated protein kinase signal transduction pathway. Mol. Cell. Biol. 16, 12471255.

Rolland, F., Winderickx, J. and Thevelein, J. M. (2001) Glucosesensing mechanisms in eukaryotic cells. Trends Biochem. Sci. 26, 310-317.

Shiozaki, K. and Russell, P. (1995) Cell-cycle control linked to extracellular environment by MAP kinase pathway in fission yeast. Nature 378, 739-743.

Shiozaki, K., Shiozaki, M. and Russell, P. (1997) Mcs4 mitotic catastrophe suppressor regulates the fission yeast cell cycle through the Wik1-Wis1-Spc1 kinase cascade. Mol. Biol. Cell 8, 409-419.

Song, J. J., Rhee, J. G., Suntharalingam, M., Walsh, S. A., Spitz, D. R. and Lee, Y. J. (2002) Role of glutaredoxin in metabolic oxidative stress. Glutaredoxin as a sensor of oxidative stress mediated by $\mathrm{H}_{2} \mathrm{O}_{2}$. J. Biol. Chem. 277, 46566-46575.

Spitz, D. R., Sim, J. E., Ridnour, L. A., Galoforo, S. S. and Lee, Y. J. (2000) Glucose deprivation-induced oxidative stress in human tumor cells: A fundamental defect in metabolism? Ann. N. Y. Acad. Sci. 899, 349-362.

Springael, J.-Y. and Penninckx, M. J. (2003) Nitrogen-source regulation of yeast $\gamma$-glutamyl transpeptidase synthesis involves the regulatory network including the GATA zinc-finger factor Gln3, Nil1/Gat1 and Gzf3. Biochem. J. 371, 589-595.

Stettler, S., Warbrick, E., Prochnik, S., Mackie, S. and Fantes, P. (1996) The wis1 signal transduction pathway is required for expression of cAMP-repressed genes in fission yeast. J. Cell Sci. 109, 1927-1935.

Takahashi, H. and Watanabe, H. (2004) Post-translational processing of Neisseria meningitidis $\gamma$-glutamyl transpeptidase and its association with inner membrane facing to the cytoplasmic space. FEMS Microbiol. Lett. 234, 27-35.

Takahashi, H., Hirose, K. and Watanabe, H. (2004a) Necessity of meningococcal $\gamma$-glutamyl transpeptidase for Neisseria meningitidis growth in rat cerebrospinal fluid (CSF) and CSFlike medium. J. Bacteriol. 186, 244-247.

Takahashi, H., Kuroki, T., Watanabe, Y., Dejsirilert, S., Saengsuk, L., Yamai, S. and Watanabe, H. (2004b) Reliability of the detection of meningococcal $\gamma$-glutamyl transpeptidase as an identification marker for Neisseria meningitidis. Microbiol. Immunol. 48, 485-487.

Toda, T., Shimanuki, M. and Yanagida, M. (1991) Fission yeast genes that confer resistance to staurosporine encode an AP-1like transcription factor and a protein kinase related to the mammalian ERK1/MAP2 and budding yeast FUS3 and KSS1 kinases. Genes Dev. 5, 60-73.

Toone, W. M., Kuge, S., Samuels, M., Morgan, B. A., Toda, T. and Jones, N. (1998) Regulation of the fission yeast transcription factor Pap1 by oxidative stress: requirement for the nuclear export factor $\mathrm{Crm} 1$ (exportin) and the stressactivated MAP kinase Sty1/Spc1. Genes Dev. 12, 23042-23049.

Van Dam, H., Wilhelm, D., Herr, I., Steffen, A., Herrlich, P. and Angel, P. (1995) ATF-2 is preferentially activated by stressactivated protein kinases to mediate c-jun induction in response to genotoxic agents. $E M B O J . \mathbf{1 4}, 1798-1811$.

Vincent, O. and Carlson, M. (1998) Sip4, a Snf1 kinase-dependent transcriptional activator, binds to the carbon source-responsive element of gluconeogenic genes. EMBO J. 17, 7002-7008.

Walther, K. and Schuller, H. J. (2001) Adr1 and Cat8 synergistically activate the glucose-regulated alcohol dehydrogenase gene $A D H 2$ of the yeast Saccharomyces cerevisiae. Microbiol. 147, 2037-2044.

Zhang, H., Dickinson, D. A., Liu, R. M. and Forman, H. J. (2005) 4-Hydroxynonenal increases $\gamma$-glutamyl transpeptidase gene expression through mitogen-activated protein kinase pathways. Free Radic. Biol. Med. 38, 463-471. 